\title{
Coffee seed physiology
}

\author{
Mirian T. S. Eira ${ }^{*}$, E. A. Amaral da Silva ${ }^{2}$, Renato D. de Castro ${ }^{3}$, Stéphane Dussert ${ }^{4}$, Christina Walters ${ }^{5}$, J. \\ Derek Bewley ${ }^{6}$ and Henk W. M. Hilhorst ${ }^{7}$
}

\begin{abstract}
${ }^{1}$ Embrapa Café/Embrapa Recursos Genéticos e Biotecnologia, CP 02372, 70770-900, Brasilia, DF, Brasil; ${ }^{2}$ Universidade Federal de Lavras, CP 3037, 37200-000, Lavras, MG, Brasil; ${ }^{3}$ Universidade Católica do Salvador, Av. Prof. Pinto de Aguiar 2589, Pituacu, 41740-090, Salvador, BA, Brasil; ${ }^{4}$ Institut de Recherche pour le Développement, UR141, 911 Avenue d'Agropolis, BP 64501, Montpellier, France; ${ }^{5}$ USDA-ARS National Center for Genetic Resources Preservation, 1111 South Mason Street, Fort Collins, Colorado, USA; ${ }^{6}$ University of Guelph, Department of Molecular and Cellular Biology, Axelrod Building, Ontario N1G 2W1, Canada; ${ }^{7}$ Wageningen University, Laboratory of Plant Physiology, Arboretumlaan 4, 6703 BD Wageningen, The Netherlands; *Corresponding author: mirian.eira@embrapa.br
\end{abstract}

Considerable advances in our understanding of coffee seed physiology have been made in recent years. However, despite intense research efforts, there are many aspects that remain unclear. This paper gives an overview of the current understanding of the more important features concerning coffee seed physiology, and provides information on recent findings on seed development, germination, storage and longevity.

Key words: Coffea, coffee, germination, germplasm, longevity, seed development, storage.

Fisiologia da semente do cafeeiro: Avanços consideráveis no entendimento da fisiologia de sementes do cafeeiro foram obtidos nos últimos anos. No entanto, apesar da extensa literatura, muitos aspectos permanecem obscuros. Este trabalho descreve o estado atual do conhecimento sobre as principais características da fisiologia de sementes de cafeeiro, assim como os recentes trabalhos sobre o desenvolvimento, germinação, armazenamento e longevidade das sementes.

Palavras-chave: Coffea, armazenamento, café, desenvolvimento, germinação, germoplasma, longevidade.

\section{INTRODUCTION}

Coffee is a member of the Rubiaceae family and the genus Coffea. There are more than 70 species of coffee but only two are economically important: Coffea arabica L. and Coffea canephora Pierre; $70 \%$ of the coffee traded in the world is arabica and $30 \%$ is robusta (C. canephora). Other species such as $C$. congensis, $C$. dewevrei and $C$. racemosa have some interesting genetic characteristics, including resistance to pests and diseases and are used in breeding programs. To satisfy the demand for coffee within Brazil and around the world, intensive breeding programs have been undertaken to create new cultivars which are resistant to diseases and insects, and to incorporate new traits of value. In addition, new production and processing technologies are introduced every year, which have led to an enormous improvement in coffee production. Although progress has been made, not many studies have been devoted to the improvement of coffee seed quality for propagation.
The purpose of this paper is to review our understanding of coffee seed physiology. Most of the work published in the literature and reported in this paper is on C. arabica seeds, although some aspects of $C$. canephora seed physiology are also included. Knowledge of seed physiology of other Coffea species is poor, with the exception of storage physiology, which is mostly related to germplasm conservation. Although this review will discuss some aspects of seed development and morphology, germination and storage physiology, the focus will be on germinability, and desiccation tolerance, with emphasis on the conservation of genetic resources.

\section{THE COFFEE SEED}

The coffee seed is elliptical or egg-shaped, planeconvex, possessing a longitudinal furrow on the plane surface (Dedecca, 1957). The outer cover of the seed is formed by a hard pale brown endocarp that becomes the "parchment" after drying. The endocarp contains an enclosed seed, which has 
a thin, green testa known as the spermoderm or "silver skin" (figure 1), which is a remnant of the perisperm (Mendes, 1941). In C. canephora seeds the spermoderm is adherent and brown (Fazuoli, 1986). Measurements made with a large number of seeds of Coffea arabica indicate that the seeds are 10 to $18 \mathrm{~mm}$ long and 6.5 to $9.5 \mathrm{~mm}$ wide (Dedecca, 1957). Other species such as C. racemosa have smaller seeds (5-7 mm long and 3-3.5 mm wide; Guerreiro Filho, 1992), while in C. liberica seeds are larger (figure 2).

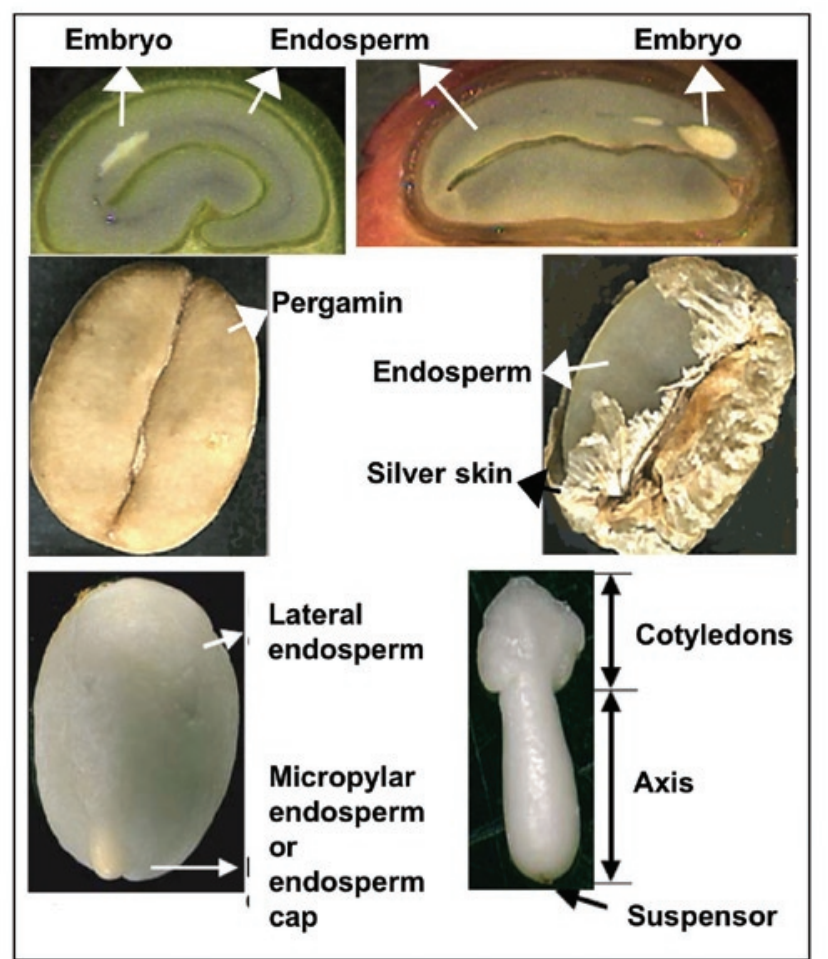

Figure 1. Cross section of a coffee seed showing the folding of the endosperm and embryo localization. Coffee seed with the pergamin. Imbibed coffee seed (Coffea arabica cv. Rubi) with endocarp removed, showing the endosperm cap and lateral endosperm. Observe the appearance of a protuberance in the endosperm cap and remnants of the spermoderm or "silver skin" on the surface at the basal end of the seed. Imbibed coffee embryo isolated after 7 days of imbibition in water, showing the cotyledons, the embryonic axis and remnants of the suspensor at the radicle tip.

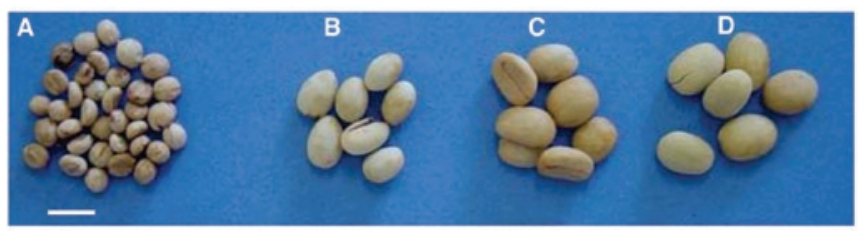

Figure 2. Coffea seeds of different sizes. A- C. racemosa; B- C. canephora; C- C. arabica; D- C. liberica. The bar corresponds to $1 \mathrm{~cm}$.
The endosperm, which is a living tissue, contains a hard external region and soft internal region, which surround the embryo (Krug and Carvalho, 1939; Mendes, 1941; Dedecca, 1957; De Castro and Marraccini, 2005). The part of the endosperm in front of the radicle tip is referred to as endosperm cap or micropylar endosperm and around the rest of the embryo is the lateral endosperm (da Silva et al., 2004) (figure 1). The endosperm tissue has a high content of polysaccharides (Wolfrom et al., 1961). The cell walls are composed of cellulose and hemicelluloses, mainly insoluble mannans (Huxley, 1964; Wolfrom and Patin, 1964). The lateral endosperm is extremely hard because the mannan is deposited there as very thick cell walls; in the micropylar region, however, the walls are much thinner (Gong et al., 2004). Coffee mannans contain $2 \%$ of galactose, as a side chain to the mannan backbone (Bewley and Black, 1994); mobilization of the endosperm cell walls following germination likely provides for a source of carbohydrate for the growing seedling. Protein, lipids and minerals are present in the cytoplasm of the endosperm cells and are probably another source of reserves (Dentan, 1985).

The embryo is very small, 3 to $4 \mathrm{~mm}$ long and is composed of an axis and two adherent cordiform cotyledons (figure 1); it is localized close to the convex surface of the seed (Dedecca, 1957; Huxley, 1964; Rena et al., 1986). The embryo contains few storage reserves, and depends upon the endosperm for nutrients until the seedling become autotrophic (Giorgini and Campos, 1992). Polyembryony and empty seeds have been observed in coffee at a frequency of $1.2 \%$ (Mendes, 1941).

\section{SEED DEVELOPMENT}

In coffee, seed production is typically characterized by asynchronous flowering and fruit development. Anthesis in arabica coffee can occur on a single day or during a few days, with one or more flowerings within a single reproductive period (Wormer, 1964; Alvim, 1973). Each flowering period lasts only 2 or 3 days and is followed by intense vegetative development.

Fruits may not initiate growth immediately after flowering, but may remain in a latent state of up to 60 days after pollination or anthesis (DAA); C. arabica is characterized by cleistogamic self-pollination (Wormer, 1964; Ramaiah and Vasudeva, 1969; De Castro et al., 2004). This latent state may persist until all flowering and favorable environmental conditions for growth are completed, i.e. a minimum availability of water, which is generally attained during subsequent rainy months of the summer season in the 
tropics, such as in Peru, Brazil, Kenya and India (Wormer, 1964; Ramaiah and Vasudeva, 1969; Alvim, 1973; Maestri and Barros, 1977; Estanislau, 2002; De Castro et al., 2004).

The initial expansion of the fruit is due to the growth of the transient perisperm that is originated from the maternal nucellus tissue (Wormer, 1964; Ramaiah and Vasudeva, 1969). For a general morphological and anatomical analysis of coffee fruit and seed during development, see Marraccini et al. (2001), Estanislau (2002), De Castro et al. (2004) and De Castro and Marraccini (2005).

The fully differentiated coffee embryo (225 to 255 DAA) is enveloped by the soft endosperm tissue (Krug and Carvalho, 1939; Mendes, 1941; De Castro and Marraccini, 2005). During embryo development hypocotyl formation was once thought to be preceded by that of the cotyledons, with embryo development occurring after endosperm development (Arcila-Pulgarín and Orozco-Castaña, 1987). However, recent observations suggest that hypocotyl formation precedes that of the cotyledons and that embryo development occurs after a lag, but in synchrony with endosperm development (Estanislau 2002; De Castro and Marraccini, 2005).

Observations made at the Coffee Genebank of the Instituto Agronômico de Campinas, in Brazil, have shown that the length of the seed maturation process is different depending on the species. C. arabica seeds are mature after 210-250 DAA, while $C$. canephora seeds take 300-350 days, C. dewevrei and C. liberica around 360 days, and C. racemosa only 90 days (Medina Filho et al., 1984; Carvalho et al., 1991).

Water Content and Dry Weight: During the initial stages of coffee fruit development water content is relatively high at around $80 \%$ (fresh weight basis), but decreases during further development, concomitant with an increase in dry weight. There are distinct patterns of dry weight changes in the whole fruit, the seed and the embryo (figure 3), as cell division and differentiation are completed and the maturation phase is initiated (Wormer, 1964; Ramaiah and Vasudeva, 1969; Estanislau, 2002; De Castro et al., 2004). The variation in water content between whole fruit and its component parts appears to be related to the coffee species, cultivar and climatic conditions during development (Wormer, 1964; Ramaiah and Vasudeva, 1969; Guimarães, 1999). Despite this variation, the embryo and seed water contents both reach around $50 \%$ by the end of maturation, whereas the fruit water content is maintained at around $70 \%$, apparently as a result of the mucilaginous mesocarp, which is also a characteristic of the ripe cherry fruits (Wormer, 1964; Ramaiah and Vasudeva, 1969; Estanislau, 2002). The increase in fruit dry weight is mainly due to an increase in seed dry weight, which is mostly endosperm, and shows a steeper percentage of dry matter or reserves accumulation during maturation as compared to the whole fruit (Wormer, 1964; Ramaiah and Vasudeva, 1969) or to the isolated embryo (Estanislau, 2002; De Castro et al., 2004) (figure 3). The seed may lose dry weight once maturity is achieved, whereas the whole fruits may still accumulate dry weight if attached longer to the parent plant. Slight decreases in seed dry weight once maturity is attained can be explained by an interruption of the translocation of photoassimilates from the fruit to the seed, as well as by substrate consumption necessary for respiration during the fully mature stages (Carvalho and Nakagawa, 1980). The loss of seed dry weight could also be due to deterioration, commonly noted in the seeds that remain in the field after physiological maturity. Alternatively, the continuous accumulation of dry weight in whole fruits could result from the translocation or exchange of photoassimilates between the fruit (pulp) and the seed with a net efflux from the seed to the fruit, at a stage when the pericarp (mesocarp) is accumulating sugars.

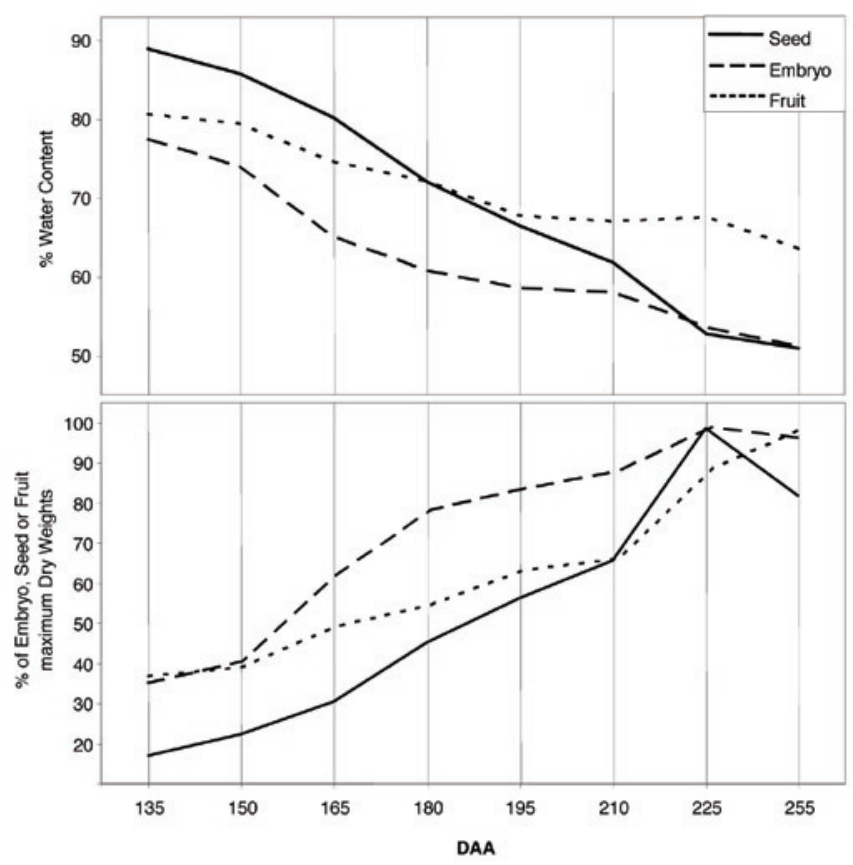

Figure 3. Water content (fresh weight basis) during development of whole coffee fruits, isolated seeds and isolated embryos. Due to their small size at the early stages of development, isolation of seeds and embryos was only possible from 120 DAA onwards. Accumulation of dry weight in coffee fruits, seeds and embryos during development. 
Acquisition of germinability: Although not yet fully differentiated and developed, cotyledonary embryos isolated from seeds of $C$. arabica between 120 and 150 DAA are able to germinate and develop into seedlings when directly incubated on Murashige and Skoog (MS) culture medium, demonstrating that embryos acquire the ability to germinate when immature (table 1; Estanislau, 2002). The change of the developmental program into a germination program in coffee embryos seems not to depend on previous desiccation, which is the case for castor bean seeds (Bewley et al., 1989), neither does it depend on the complete differentiation of the embryo as in other species, such as tomato and maize (Berry and Bewley, 1991; 1992; Bochicchio et al., 1996; De Castro and Hilhorst, 2000). On the other hand, whole seeds are able to germinate on water only when isolated from yellowishgreen fruits at around 225 DAA (table 2; Estanislau, 2002), corroborating the observations of Carvalho and Alvarenga (1979). This demonstrates a repression of the germination of immature embryos when enclosed in the developing coffee seeds, indicating the existence of a mechanism that maintains the embryo and the seed in a developmental mode while on the parent plant. In fact, the osmotic condition of the milky endosperm may contribute to keeping the embryo in the developmental mode. Precocious germination, prior to

Table 1. In vitro germination percentage on MS medium of isolated embryos of $C$. arabica before and after drying.

\begin{tabular}{cccc}
\hline DAA & FRESH & FD & SD \\
\hline 150 & 97 & 0 & 0 \\
165 & 91 & 5 & 8 \\
180 & 94 & 5 & 0 \\
195 & 97 & 2 & 38 \\
210 & 94 & 13 & 77 \\
$225-$ YG & 97 & 83 & 97 \\
$225-$ Ch & 100 & 58 & 94 \\
\hline
\end{tabular}

Scott-Knott test $(\mathrm{p}<0,05)$. CV $=18,7$.

FD - Fast Drying; SD - Slow Drying; YG - Yellowish Green; Ch - Cherry.

Table 2. Germination percentage of seeds of $C$. arabica on water before and after drying.

\begin{tabular}{cccc}
\hline DAA & FRESH & FD & SD \\
\hline 150 & 0 & 0 & 0 \\
165 & 0 & 0 & 0 \\
180 & 0 & 0 & 0 \\
195 & 0 & 0 & 0 \\
210 & 0 & 3 & 21 \\
$225-\mathrm{YG}$ & 97 & 92 & 89 \\
$225-\mathrm{Ch}$ & 96 & 92 & 90 \\
\hline
\end{tabular}

Scott-Knott test $(\mathrm{p}<0,05)$. CV $=10,5$.

FD - Fast Drying; SD - Slow Drying; YG - Yellowish Green; Ch - Cherry. physiological maturity, is observed in many seeds, including cotton, wheat, soybean, bean and tomato, when they are isolated and incubated on a wet substrate (Carvalho and Yanai, 1976; Jacinto and Carvalho, 1974; Silva, 1974; Berry and Bewley, 1991; De Castro and Hilhorst, 2000).

\section{GERMINATION PHYSIOLOGY}

Mature (dried) coffee seeds show slow and asynchronous germination, which makes it difficult to obtain seedlings that are ideal for establishment of coffee crops and coffee production. Little work has been done to understand coffee seed germination and its regulation. Such studies are essential for the improvement of agricultural practices and further development of coffee production.

Germination Characteristics: Coffee seeds germinate slowly in the field (Rena et al., 1986). C. arabica seedling emergence from the soil starts 50 to 60 days after sowing in the warmer periods of the year (Maestri and Vieira, 1961). When temperatures are lower the emergence period may increase to 90 days (Went, 1957). Following germination, the coffee cotyledons grow by absorbing the endosperm and turn green (Wellman, 1961; Giorgini and Campos, 1992). The first seed parts to emerge from the soil are the cotyledons, characterizing epigeal seedling growth, and 3 to 4 weeks are required for the cotyledons to completely deplete the endosperm and be free from any residuum of it (Huxley, 1964).

The presence of the endocarp drastically inhibits the germination of coffee seeds (Valio, 1980) and it is generally removed before any germination tests. Radicle protrusion in C. arabica seeds under optimal (e.g. laboratory) conditions $\left(30^{\circ} \mathrm{C}\right.$, in the dark) starts around day 5 or 6 of imbibition and $50 \%$ of the seed population displays radicle protrusion by day 10 . At day 15 of imbibition most of the seeds have completed germination (Valio, 1980; da Silva et al., 2004). Obviously, germination is faster under optimal conditions when environmental effects such as variations in daynight temperatures and soil water potential are absent. In addition, germination under field conditions is defined as seedling emergence from the soil; radicle protrusion has already been completed some time before emergence, whereas germination sensu stricto is completed with radicle emergence. The morphology of a $C$. arabica seed during or immediately following germination is shown in figure 4. Seed germination of other Coffea species is similar, although in some species that have smaller seeds, such as C. racemosa, germination is faster, occurring in 10 days or 
less (Carelli and Monaco, 1977; Medina Filho et al., 1984; Carvalho et al., 1991).

The events that take place during germination of the coffee seeds are schematically shown in figure 5. These events coincide to a large extent and are interdependent. Radicle protrusion from coffee seeds is the net result of embryo growth and endosperm weakening prior to radicle protrusion.

In the embryo, a growth and a build-up of turgor potential is observed at the beginning of germination, showing that the cells in the embryonic axis are preparing for expansion growth: the increase in turgor indicates that water is taken up by the cells but that relaxation of the walls is largely absent. This may be caused by a limitation of the cell wall extensibility at that time or by the fact that expansion is hindered by an opposing mechanical restraint of the surrounding endosperm (da Silva et al., 2004). The endosperm may enable radicle expansion by hydrolytic degradation of its cell walls; this includes increased activities of endo- $\beta$-mannanase and cellulase and results in a decrease of the required puncture force to penetrate the endosperm. In this stage also porosity in the cell walls closest to the embryo is observed. Endosperm cell wall degradation may create space for the embryo to expand, or it may increase the plasticity of the endosperm cell walls. The occurrence of the latter is supported by the appearance of a protuberance in which the growing radicle is surrounded by a still intact endosperm cap (figure 4 ). The transition from 4 to 6 days is marked by a decrease in turgor potential of the embryo and the occurrence of plateau phases in endo- $\beta$-mannanase and cellulase activities as well as the required puncture force. From day 6 onwards embryo continues to growth and the protuberance becomes more prominent.
In the endosperm cap both endo- $\beta$-mannanase and cellulase activities increase again, the required puncture force displays a second decrease, and the porosity of cell walls in the endosperm cap becomes more intense and spreads out further to the periphery of the endosperm cap. It is clear that at this stage the endosperm cap 'gives way' to the growing embryo. The cells in the endosperm cap appear compressed, reinforcing the notion that embryo 'thrust' is increasing. It is possible that the second step in endosperm weakening is partly caused by the growing embryo. Penetration of the micropylar endosperm is likely also facilitated by the presence of relatively thinner cell walls in this region (Gong et al., 2004). Degradation of the lateral endosperm commences around the time of completion of germination, likely signifying the beginning of reserve mobilization to accommodate the growing embryo (da Silva et al., 2004).

The role of abscisic acid: Abscisic acid (ABA) induces dormancy and inhibits seed germination of many species (Bewley and Black, 1994). In C. arabica seed, Valio (1976) found that endogenous ABA-like substances and exogenous ABA cause inhibition of germination by preventing embryo growth. Da Silva et al. (2004) showed the occurrence of a transient rise in endogenous ABA content during germination in the embryo cells, suggestive that ABA inhibits cell wall extensibility, by not permitting an increase in cell turgor (da Silva et al., 2004).

Exogenous ABA inhibits the second step of endosperm cap weakening and reduces the activity of endo- $\beta$-mannanase, but it also reduces the activity of endo- $\beta$-mannanase on days 3-4 of germination (da Silva et al., 2004) (figure 5). Thus,
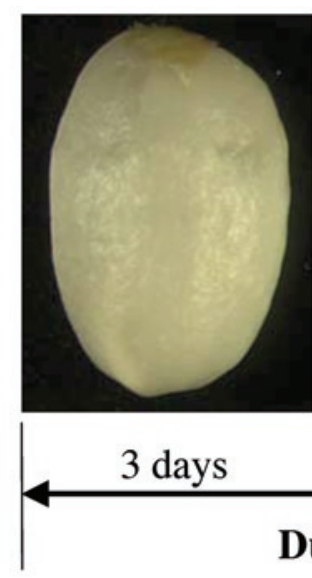

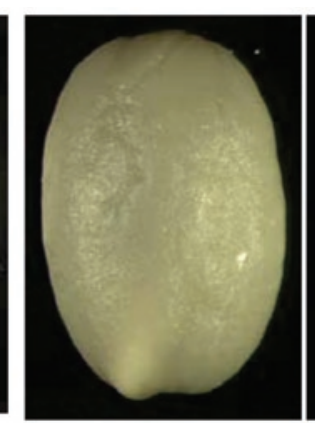

6 days

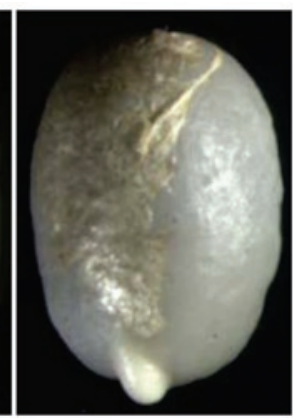

9 days

\section{During germination}
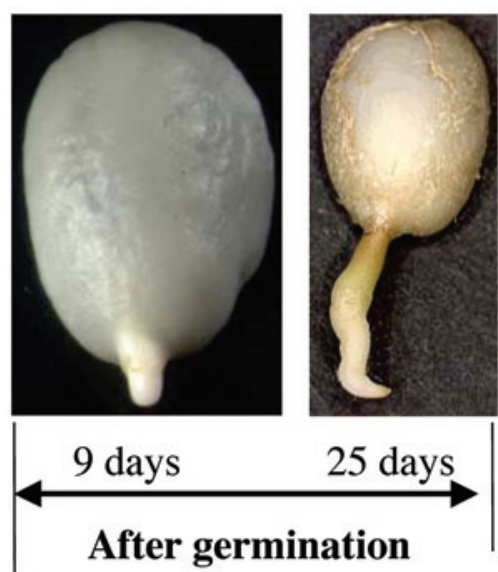

Figure 4. Coffee seed germination sensu stricto and subsequent radicle growth. A fully imbibed seed is shown at day 3 of imbibition with no visible protuberance; a protuberance is visible from day 6 of imbibition onwards and radicle protrusion starts at day 9. Following germination (days 9 and 25), the radicle grows and the endosperm remains attached to the cotyledons. The cotyledons will completely resorb the endosperm before they become green and autotrophic. 
the first phase of the decrease in the required puncture force cannot be attributed to endo- $\beta$-mannanase activity whereas the second phase may be under control of this enzyme.

There is some discrepancy in the number of isoforms of endo- $\beta$-mannanase reported for coffee seeds. Da Silva et al. (2004) reported that there are four different isoforms in the endosperm, whereas Marraccini et al. (2001) observed eight. This difference may be due to the fact that the former researchers studied seeds prior to radicle protrusion, whereas the latter used seeds after completion of germination. These results suggest that the different isoforms of endo$\beta$-mannanase have different functions during coffee seed germination and subsequent seedling growth. According to da Silva et al. (2004), ABA inhibits the activity of at least two of the different isoforms of endo- $\beta$-mannanase in the endosperm cap of coffee seed (pI 4.5 and pI 6.5).

The first step of endosperm cap weakening in coffee seed is not inhibited by ABA, and it does not inhibit cellulase activity. Indeed, an increase in cellulase activity coincides with the first phase of decrease in puncture force both in waterand ABA-imbibed seeds (da Silva et al., 2004). The presence of cellulase has previously been demonstrated in coffee seed (Takaki and Dietrich, 1980; Giorgini, 1992). Tissue printing demonstrated that cellulase activity is present throughout the endosperm during imbibition and no differences were observed with and without ABA. Thus, during coffee seed

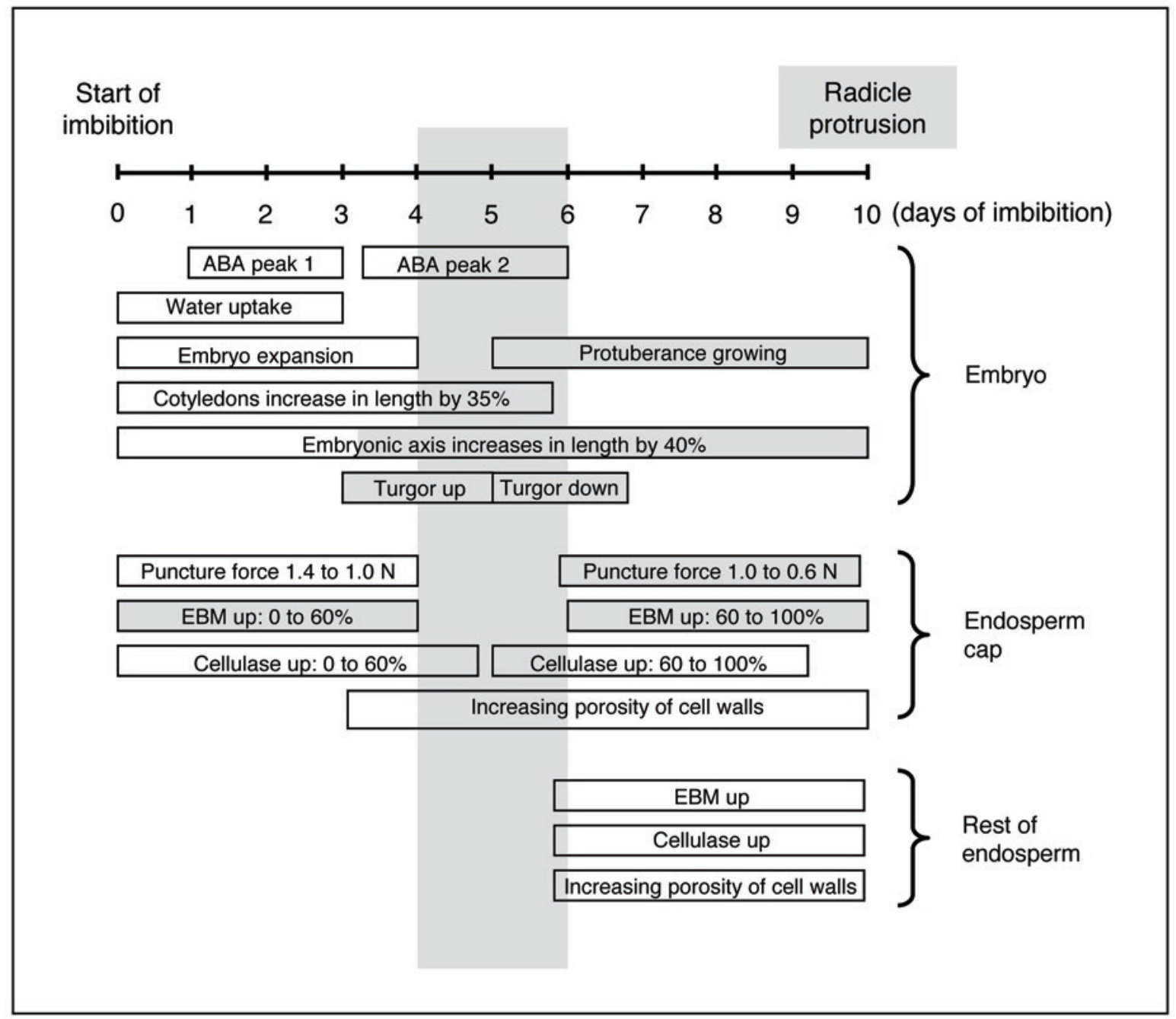

Figure 5. Schematic overview of events occurring in the embryo and endosperm during the germination of coffee seeds between the start of imbibition and radicle protrusion. Shaded bars indicate that the event is affected by ABA. EBM: endo- $\beta$-mannanase activity. \% in EBM and cellulase bars indicates activity relative to maximum. "up": indicates increase. Shaded column between 4 and 6 days of imbibition indicates transition phases of germination. Adapted from da Silva et al. (2004, 2005). 
germination a biphasic endosperm cap weakening occurs; ABA may control the second step by inhibiting the activity of two isoforms of endo- $\beta$-mannanase.

The role of gibberellins: Gibberellins (GAs) also play an important role in seed germination. The site of GA action has been proposed to be both in the endosperm and in the embryo (Karssen et al., 1989). According to da Silva et al. (2005) coffee seed depends on the de novo synthesis of GAs. Endogenous GAs are required for embryo cell elongation and endosperm cap weakening during germination.

However, contrary to many reports on the stimulatory effect of GA on seed germination and cell elongation, exogenous $\mathrm{GA}_{3}$ inhibits radicle protrusion and emergence in coffee seed (Maestri and Vieira, 1961; Valio, 1976; Takaki et al., 1979; Takaki and Drietrich, 1979, 1980). This inhibition is proposed to be caused by a build up of mannose, as a degradation product of the hydrolysis of cell-wall mannans by endo- $\beta$-mannanase and $\beta$-mannosidase (Takaki and Dietrich, 1980).

A mechanism of inhibition of Coffea arabica seed germination by exogenous GAs is proposed by da Silva et al. (2005). Supra-optimal GA concentrations may release from the endosperm one or more factors that induce cell death in the embryonic axis. These factors are proposed to be related to oxidation stress or absence of sufficient "reducing power" since the embryonic axis becomes brown in seeds imbibed in $100 \mu \mathrm{M}$ of $\mathrm{GA}_{4+7}$ very late during the germination just prior to radicle protrusion. It is possible that under these conditions normal cell death of the endosperm cap occurs too early, with respect to embryo growth. The embryo would then be affected by the damaging sugars (e.g. mannose) released from the endosperm cap cell walls during their degradation. In other words, too much GA deregulates the synchronization of germination processes occurring in the embryo and endosperm.

The inhibitory effect of light during coffee seed germination: Valio (1976) and da Silva et al. (2005) observed that coffee seeds (Coffea arabica) are sensitive to white light, which delays seed germination.

Since light causes induction of GA-biosynthesis in seeds (Hilhorst and Karssen, 1992), light could induce an increase in GA in coffee seeds. Consequently, the amount of endogenous GA induced by light is more than the amount needed for germination and the excess become toxic, affecting germination, leading to its delay (da Silva et al., 2005).
An ecological significance of the inhibitory effect of light during coffee seed germination was suggested by da Silva (2002). Coffee is originally classified as a shade plant (Rena et al., 1986). Thus, to avoid germination under full light, coffee may have developed this light/GA inhibition mechanism.

\section{SEED STORAGE PHYSIOLOGY}

Storage behavior: Mature seeds can tolerate desiccation to varying degrees. Orthodox seeds are shed at low water contents, and can tolerate further drying without damage. Recalcitrant seeds are shed from the parent plant with high water contents, are desiccation-sensitive and lose viability at relatively high water content (Roberts, 1973; King and Roberts, 1979). In addition to the orthodox and recalcitrant categories of seed storage behavior, Ellis et al. (1990, 1991) introduced the "intermediate" category of desiccation tolerance to describe seeds which can tolerate some drying but do not survive complete desiccation or the combined effects of desiccation and low temperature.

The storage physiology of seeds from Coffea is complex and the literature is often conflicting. Coffee seeds $(C$. arabica) were first classified as recalcitrant (King and Roberts, 1979). That classification could not be substantiated, as coffee seeds survive drying to water contents less than 0.20 $\mathrm{g} \mathrm{H}_{2} \mathrm{O} / \mathrm{g} \mathrm{dw}$, which is typically the threshold water content defining recalcitrant seeds (Ellis et al., 1990; Hong and Ellis, 1995; Vertucci and Farrant, 1995; Dussert et al., 1997; Eira et al., 1999a). However, the seeds do not survive complete desiccation or the combined effects of desiccation and low temperature (Ellis et al., 1990, 1991; Hong and Ellis, 1995; Dussert et al., 1997; Eira et al., 1999a). Coffee seeds are now considered to have storage behavior defined as intermediate (Ellis et al., 1990, 1991; Hong and Ellis, 1995). The major impediment to storing seeds with intermediate physiologies is an understanding of the limit to which Coffea seeds can be dried and the interaction of temperature and water content on seed survival.

Species of Coffea display a broad variability in seed desiccation sensitivity (Hong and Ellis, 1995; Dussert et al., 1999; Eira et al., 1999a). Ellis and colleagues reported that the minimum water content to which seeds of $C$. arabica, $C$. canephora and $C$. liberica can be dried without damage is

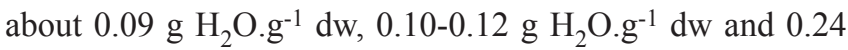

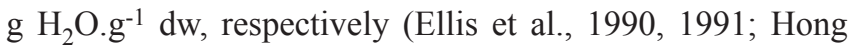
and Ellis, 1995). More recent studies of C. racemosa, $C$. sessiliflora and $C$. costatifructa suggest greater sensitivity 
to desiccation in these species with damage evident upon drying from an initial water content of $0.30 \mathrm{~g} \mathrm{H}_{2} \mathrm{O}_{\mathrm{g}} \mathrm{g}^{-1} \mathrm{dw}$ (C. racemosa and $C$. sessiliflora), or with drying to water

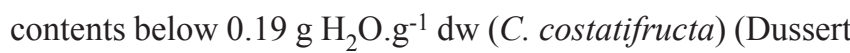
et al., 1998). Dussert et al. (1999) observed the existence of a continuum of the values of the water content at which 50 $\%$ of initial viability, $\mathrm{WC}_{50}$, is reached among coffee species, ranging from $0.05 \mathrm{~g} \mathrm{H}_{2} \mathrm{O}_{\mathrm{g}} \mathrm{g}^{-1} \mathrm{dw}$ for $C$. pseudozanguebariae to $0.38 \mathrm{~g} \mathrm{H}_{2} \mathrm{O} \cdot \mathrm{g}^{-1} \mathrm{dw}$ for C. humilis. Eira et al. (1999a) demonstrated critical water contents for whole seeds dried at $15^{\circ} \mathrm{C}$ ranging from $0.16 \mathrm{~g} \mathrm{H}_{2} \mathrm{O} \cdot \mathrm{g}^{-1} \mathrm{dw}(C$. liberica) to 0.08

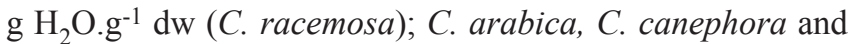
$C$. congensis had intermediate tolerances to desiccation, being damaged at water contents less than about $0.10 \mathrm{~g}$ $\mathrm{H}_{2} \mathrm{O} \cdot \mathrm{g}^{-1} \mathrm{dw}$. Critical water contents and the way they have been reported by different laboratories vary slightly but the ranking of desiccation sensitivity of Coffea species appears to be consistent.

Low temperature has detrimental effects on survival of Coffea spp. seeds. The temperature, water content of the seeds and the genetic line affect the survival observed following exposure to low temperatures. Wellman and Toole (1960) reported that "chilling" has an adverse effect on germination. Similarly, van der Vossen (1979) reported that storing arabica coffee seeds containing 0.15 to $0.50 \mathrm{~g} \mathrm{H}_{2}{\mathrm{O} . \mathrm{g}^{-1}}^{-1}$ $\mathrm{dw}$ at $5^{\circ} \mathrm{C}$ results in an immediate loss of viability. In spite of this apparent predisposal to chilling injury, there are reports of survival of coffee seeds at subzero temperatures. Early reports showed that arabica coffee seeds with water contents adjusted to $0.11-0.12 \mathrm{~g} \mathrm{H}_{2} \mathrm{O}_{\mathrm{g}} \mathrm{g}^{-1} \mathrm{dw}$ survive temperatures as low as -10 or $-16^{\circ} \mathrm{C}$ for 10 days (Wellman and Toole, 1960). Ellis and colleagues (Ellis et al., 1990) repeated these experiments for seeds of a number of $C$. arabica cultivars and observed survival after exposure to $-20^{\circ} \mathrm{C}$, only if the water content was adjusted to between 0.10 and $0.12 \mathrm{~g} \mathrm{H}_{2} \mathrm{O}_{\mathrm{g}} \mathrm{g}^{-1}$ dw. Similar results were obtained by Eira et al. (1999a) for C. racemosa, C. arabica, C. canephora, C. congensis and $C$. dewevrei. Even at ultra low temperatures such as that of liquid nitrogen $\left(-150\right.$ to $\left.-196^{\circ} \mathrm{C}\right)$ seed of several species of Coffea can survive if they are first desiccated to water

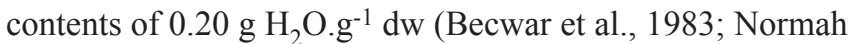
and Vengadasalam, 1992; Dussert et al., 1997, 1998; Eira et al., 1999a, 2002).

The effects of water content and temperature are interdependent and the critical water content always increases with decreasing temperature (Dussert et al., 1997, 1998; Eira et al., 1999a, b).
Short and medium term conservation: The viability of seeds of Coffea arabica L. decreases rapidly after 4-6 months at ambient temperatures, and seeds of commercial cultivars have to be distributed to the coffee nurseries within a few months after harvesting (van der Vossen, 1979; Dias and Barros, 1993; Miranda et al., 1993). Prolonging the viability of coffee seed in storage is also of considerable significance in breeding and other experimental programs. For example, when artificial hybridization programs have to be continued over more than one season, effective storage of seed for 12 months or longer is sometimes required.

Short term storage (up to 3 years) of $C$. arabica seeds was studied by several laboratories since the first experiments performed by Bacchi $(1958,1959)$ at the Instituto Agronômico de Campinas, Brazil, as reviewed by Eira et al. (1999a) and Gentil et al. (2001). The protocol of hermetic storage at $10^{\circ} \mathrm{C}$ with about $10-11 \%$ moisture content (fwb) recommended by Ellis et al. $(1990,1991)$ and Hong and Ellis $(1992,1995,2002)$ seems to be the best way to maintain seed viability in arabica coffee. C. canephora seeds should be stored with 13-15\% water content, at 10$15^{\circ} \mathrm{C}$, as suggested by Camargo et al. (1993), Hong and Ellis (1995) and Rosa et al. (2005).

Medium term storage of $C$. arabica seeds can be performed at $-20^{\circ} \mathrm{C}$, although the results in the literature do not indicate a consistent protocol of storage. Hong and Ellis (1992) reported that among seventeen seed lots of nine cultivars investigated, seeds from only two seed lots survived 1-3 years of hermetic storage at $-20^{\circ} \mathrm{C}$. Eira et al. (1999a) also reported that the great majority of seeds of 6 different cultivars of arabica coffee survive exposure to $-20^{\circ} \mathrm{C}$ for 30 days in hermetic storage with about $0.12 \mathrm{~g} \mathrm{H}_{2} \mathrm{O} / \mathrm{g} \mathrm{dw}$, in equilibrium with about $50 \%$ relative humidity at $25^{\circ} \mathrm{C}$ (Eira et al., 1999b), whereas at higher or lower moisture content treatments viability is lost rapidly. Current results, therefore, show that there is a narrow window of seed moisture status at which the medium-term hermetic storage of certain arabica coffee seed lots at $-20^{\circ} \mathrm{C}$ is feasible. That protocol cannot be applied to all cultivars of $C$. arabica and according to Hong and Ellis (2002), seed lots that maintained viability under those conditions are exceptional in their ability both to withstand desiccation and to survive medium-term storage. In other species of Coffea deterioration is slowest in seed samples stored at $-20^{\circ} \mathrm{C}$ if seeds are firstly equilibrated over solutions at that same relative humidity (43-50\%), although they reach different final water contents (Eira et al., 1999a, b); 
however, for all species studied, viability loss under storage at $-20^{\circ} \mathrm{C}$ occurs after one year of storage (Eira, 1999). A systematic investigation of the factors involved in the storage of Coffea species under $-20^{\circ} \mathrm{C}$ needs to be performed.

Long term conservation: Viability of seeds stored in genebanks must be maintained for several years or even centuries. There is a great genetic variability between and within Coffea species, which is of importance for breeding (Fazuoli, 1986). Because of the difficulties of storing the seed, coffee germplasm is maintained in field collections, presenting significant problems, such as land and labor costs, susceptibility to environmental hazards and pathogens (Berthaud and Charrier, 1988). Storage of Coffea species in ex situ genebanks may help to preserve the threatened diversity of this important genus. Since 1976 the International Plant Genetic Resources Institute (IPGRI, formerly IBPGR) has considered coffee as a high priority for genetic conservation (Simmonds, 1979).

For non-orthodox seed species, cryopreservation is the only technique available for long-term germplasm conservation. In the case of intermediate seed-propagated species, seeds are partially desiccation tolerant and, therefore, the option which has to be always tested first is whole-seed cryopreservation.

Some work has been carried out on the cryostorage of coffee seeds. Stanwood (1985) classified C. arabica seeds as desiccation tolerant and liquid nitrogen sensitive; also, Hor et al. (1993) working with C. liberica seeds, reported no survival after liquid nitrogen exposure. Nevertheless, Becwar et al. (1983) suggested that C. arabica seeds cv. Bourbon tolerate desiccation as low as $0.08 \mathrm{~g} / \mathrm{g}$ but do not survive direct exposure to liquid nitrogen at that water content. However, at $0.17 \mathrm{~g} / \mathrm{g}$ (fwb) and cooling rate of $2^{\circ} \mathrm{C} /$ minute down to $-80^{\circ} \mathrm{C}$, at least $60 \%$ of the seeds survived cryopreservation. Normah and Vengadasalam (1992) showed that seeds of $C$. liberica can survive storage in liquid nitrogen if the water content is around $0.17 \mathrm{~g} / \mathrm{g}$ (fwb). Eira et al. (1999a) reported survival of C. arabica and C. racemosa seeds with $0.20 \mathrm{~g} / \mathrm{g}$ $\mathrm{dw}$ after liquid nitrogen exposure. According to those results, coffee seeds are not liquid nitrogen sensitive at appropriate water contents of around $0.17 \mathrm{~g} / \mathrm{g}$ (fwb) or $0.20 \mathrm{~g} / \mathrm{g}(\mathrm{dwb})$.

Using nine different coffee species, the basis of the limits of the hydration window for intermediate seed cryopreservation has been investigated recently (Dussert et al., 2001). When expressed in terms of water content, the higher limit (HL) of the hydration window is highly variable but corresponds always to the seed unfrozen water content ( $0.20 \mathrm{~g}$ of water per $\mathrm{g}$ dry weight, as reported by Eira et al., 1999a), as determined by DSC (differential scanning calorimetry) analysis, suggesting that seed survival depends on avoidance of intracellular ice formation (Vertucci, 1990). Those results for $C$. arabica are illustrated in figure 6 . When expressed in terms of water activity, the interspecific variability in HL is very low, suggesting that desiccating under 75-86 \% RH ensures an acceptable hydration level for the cryopreservation of Coffea seeds. Dussert et al. (2001) classified the Coffea species in three groups. $C$. brevipes, C. canephora, C. liberica and C. stenophylla are part of Group 1, where no germination occurs after liquid nitrogen exposure, independently of water content or cooling procedure, although embryos extracted from cryopreserved seeds can germinate in vitro. C. arabica and C. eugenioides are part of Group 2, where only little recovery is obtained after cryopreservation. And C. pseudozanguebariae, $C$. racemosa and $C$. sessiflora are in Group 3, where very high percentage of germination, radicle growth and normal seedlings are obtained after liquid nitrogen exposure.

In species of Group 1, cryopreserving whole seeds and rescuing zygotic embryos in vitro after thawing represents a valuable alternative option for long-term germplasm conservation (Dussert et al., 1997). This method avoids many of the problems encountered with traditional zygotic embryo cryopreservation protocols. Equilibrium drying of whole seeds provides high reproducibility in comparison with drying methods classically employed with zygotic embryos: i.e. in the laminar air flow of a sterile cabinet or using silica-gel. Cryopreservation of whole seeds also allows the processing of large amounts of seeds at the same time. Moreover, aseptic conditions are required only after thawing. By contrast, excision of zygotic embryos prior to cryopreservation is highly time-consuming and labor intensive.

Researchers at IRD (Institut de Recherche pour le Développement) in Montpellier, France, have developed a cryopreservation procedure, entailing freezing in liquid nitrogen at $196^{\circ} \mathrm{C}$, for Coffea arabica in four steps, each requiring specific values of the parameters involved: desiccation, freezing, rewarming and rehydration of seeds (IRD, 2000). The seeds must be desiccated to a very precise point ( $0.20 \mathrm{~g}$ of water per $\mathrm{g}$ dry weight) obtained after three weeks of equilibration under $80-81 \%$ RH. Freezing must be done in two stages, vital for successful cryopreservation: a slow-cooling step at $1{ }^{\circ} \mathrm{C}$ per minute down to $50^{\circ} \mathrm{C}$, followed 
by rapid immersion in liquid nitrogen. Rapid rewarming and thawing is carried out before controlled rehydration, which is obtained by seed culture on low-osmotic potential solutions (Dussert et al., 2000, 2003), i.e. in an aqueous solution which allows rehydration to proceed more slowly. The method has recently been applied at the CATIE (Centro Agronomico Tropical de Investigation y Ensenãnza in Costa Rica) on about 100 genotypes of the species representative of the genetic diversity of the collection of coffee trees grown at that research institute (Vasquez et al., 2005).

The genebank of Embrapa Genetic Resources and Biotechnology in Brazil has also established a program to cryo-

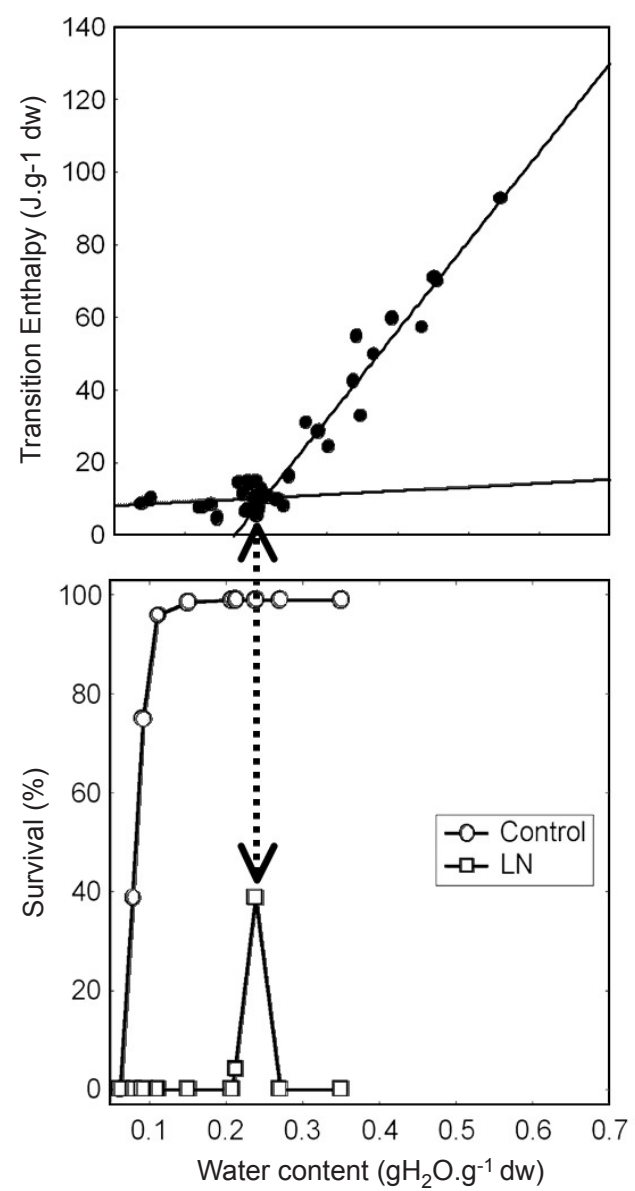

Figure 6. Correspondence between the optimal water content for $C$. arabica seed cryopreservation $(\square, \mathrm{LN})$ and the seed unfrozen water content, as calculated by the X-intercept of the intersection between the two lines of regression $(\mathbf{O})$ which best fitted the relationship between water content and enthalpy of the melting transitions of seed samples dried to various water contents. Note that the lower limit of the hydration window for seed cryopreservation does not correspond to the level of seed desiccation tolerance $(O$, control) when expressed in terms of water content. Adapted from Dussert et al. (2001, 2003). preserve genetic resources of Coffea. The protocol was first determined for Coffea arabica and is now being adapted to other species of Coffea (Eira et al., 2004).

Basis of desiccation sensitivity: Several studies have been carried out aiming to elucidate the basis of the desiccation sensitivity of Coffea seeds, and some recent results are discussed.

Water sorption isotherms describe the relationships between water content, relative humidity and temperature. A comparison among seed tissues of cultivars of $C$. arabica and different species of Coffea was performed by Eira et al. (1999b) to test the hypothesis that sorption characteristics vary in tissues differing in desiccation tolerance. There were no apparent differences in sorption characteristics among whole seeds or embryos of several cultivars of $C$. arabica and among different species of Coffea, although there were substantial differences observed between embryos and whole seeds. The shape of isotherms of coffee seed tissues was intermediate to the reverse sigmoidal shape observed for orthodox seeds and the monotonic shape observed for desiccation intolerant plant tissues. The heats of sorption calculated for RH $£ 25 \%$ for whole seeds of Coffea spp. were similar to orthodox seeds. In contrast, the heats of sorption calculated in the same RH range for excised embryos were intermediate between those of orthodox and recalcitrant embryos. Those observations are consistent with earlier observations that desiccation sensitivity or poor longevity is linked with low amounts of water sorption at relative humidities less than $25 \%$ (Vertucci and Leopold, 1987; Vertucci and Roos, 1990; Vertucci et al., 1994; Sun et al., 1997). The intermediate sorption characteristic of Coffea seeds is intriguing because the physiology of the seed, in terms of desiccation tolerance and longevity, is also classified as intermediate (Ellis et al., 1990, 1991; Hong and Ellis, 1995; Dussert et al., 1998, 1999; Eira et al., 1999a). This consistency suggests a relationship between water properties and physiology; however, the nature of the relationship remains evasive.

Soluble sugars have been proposed to play an important role in the desiccation tolerance and the high storability of orthodox seeds (Leopold et al., 1994; Vertucci and Farrant, 1995; Pammenter and Berjak, 1999). Two main hypotheses explain the potential beneficial effects of soluble sugar accumulation: the 'water replacement' hypothesis (Crowe et al., 1992) and vitrification of the aqueous phase (Williams and Leopold, 1989; Leopold et al., 1994). Brandão Junior 
(2000) observed an accumulation of glucose during the maturation process of $C$. arabica seeds; however, reduction of the glucose concentration during seed drying was also observed. Chabrillange et al. (2000) studied the possibility of using seed sugar composition as an indicator of seed behavior in ten coffee species. The sucrose content, the total soluble sugar content and the oligosaccharide/sucrose (O:S) ratio were not correlated with seed desiccation sensitivity, as estimated by the water content and the water activity at which half of the initial viability was lost. Moreover, there was no association between the presence/absence of oligosaccharides and seed desiccation sensitivity. Thus, in contrast to the results of Lin and Huang (1994) and Steadman et al. (1996), none of the variables resulting from seed sugar analysis constituted a good indicator of the intraspecific variability for seed desiccation sensitivity among coffee species. This result supports those reviewed by Vertucci and Farrant (1995) and Pammenter and Berjak (1999), which suggest that soluble sugars alone do not confer seed desiccation tolerance.

Studying the genetic determinism of seed desiccation sensitivity using crosses between species/genotypes exhibiting a high difference for this trait represents an interesting alternative approach to investigate the cause of the interspecific variability observed for seed desiccation tolerance in the genus Coffea. Such an approach has already been used for studying variability in seed longevity in rice (Miura et al., 2002) and Arabidopsis thaliana (Bentsink et al., 2000) and for the genetic analysis of several compounds that contribute to coffee brew quality, such as seed chlorogenic acid content (Campa et al., 2003). Dussert et al. (2004) investigated the inheritance of seed desiccation sensitivity using a cross between C. pseudozanguebariae and C. liberica var. dewevrei, two coffee species which display significant differences in seed desiccation sensitivity (Dussert et al., 1999, Eira et al., 1999a). Throughout the study, seed desiccation tolerance was quantified both in terms of water content and water activity. Whatever the parameter used, the extent of seed desiccation tolerance in F1 hybrids corresponded to that of the midparent, thus indicating an additive inheritance of seed desiccation tolerance at the F1 level. A broad variation was observed among hybrids backcrossed to C. liberica (BCs) for seed desiccation tolerance, independent of the parameter used to quantify it. This variation was continuous and BCs showed transgression in the direction of the most desiccation sensitive parent, indicating: i) that desiccation tolerance is a polygenic trait in coffee species, a fact which is in agreement with the common understanding that seed desiccation tolerance is a multi-factorial trait and, ii) that C. pseudozanguebariae does not harbour the most favourable alleles for all the genes involved in seed desiccation tolerance. No significant difference was observed between the two reciprocal backcrosses, F1 x C. liberica and C. liberica $\times$ F1, for the extent of desiccation tolerance of their seeds, showing the absence of maternal effect on this trait. The possibility of mapping QTLs controlling seed desiccation tolerance in a large population of C. pseudozanguebariae x C. liberica BCs is currently being tested.

The biochemical and physiological bases of $C$. arabica seed storage behavior on coffee seed viability and antioxidant, lipid and sugar status were examined recently (Dussert et al., 2006) by investigating the effects of equilibrium drying at 9-81\% relative humidities $(\mathrm{RH})$, and storage at 20 or $5^{\circ} \mathrm{C}$. Slow drying (equilibration method) induced a significant decrease in the concentrations of the pools of two major antioxidants, glutathione and ascorbate, and an increase in the free fatty acid (FFA) content of seeds, independent of the RH employed. Seeds stored at $81 \% \mathrm{RH}$ and $20^{\circ} \mathrm{C}$ lost their viability very rapidly and accumulated FFA (figure 7), underwent an extensive loss and oxidation of antioxidants, and a selective loss of phospholipids, in particular phosphatidylethanolamine (PE). Interestingly, the changes in PE content were not due to fatty acid deesterification, for the increase in FFA resulted from neutral lipid hydrolysis. Decreasing the storage temperature to $5^{\circ} \mathrm{C}$ considerably slowed the loss of seed viability, the amount of oxidative stress and the rate of lipid hydrolysis. No decline in seed viability occurred under storage conditions of $45 \% \mathrm{RH} /$ $20^{\circ} \mathrm{C}$. After 1 year at $45 \% \mathrm{RH} / 5^{\circ} \mathrm{C}$, the loss of seed viability was due to imbibitional damage and could be circumvented by pre-humidifying or pre-heating seeds before sowing.

\section{PERSPECTIVES}

Considerable advances have been made in our understanding of the morphology, anatomy and molecular physiology of coffee seed development, germination and storage. Yet, we are far from understanding many crucial events such as the uneven development and maturation of coffee fruits and seeds, as observed in most commercial cultivars. Understanding the influence of environmental effects on flowering, fruit set and development is also a great challenge, i.e. how do coffee plants sense and respond to environmental changes with respect to flowering and fruit development? Further research on the different levels of desiccation sensitivity among 

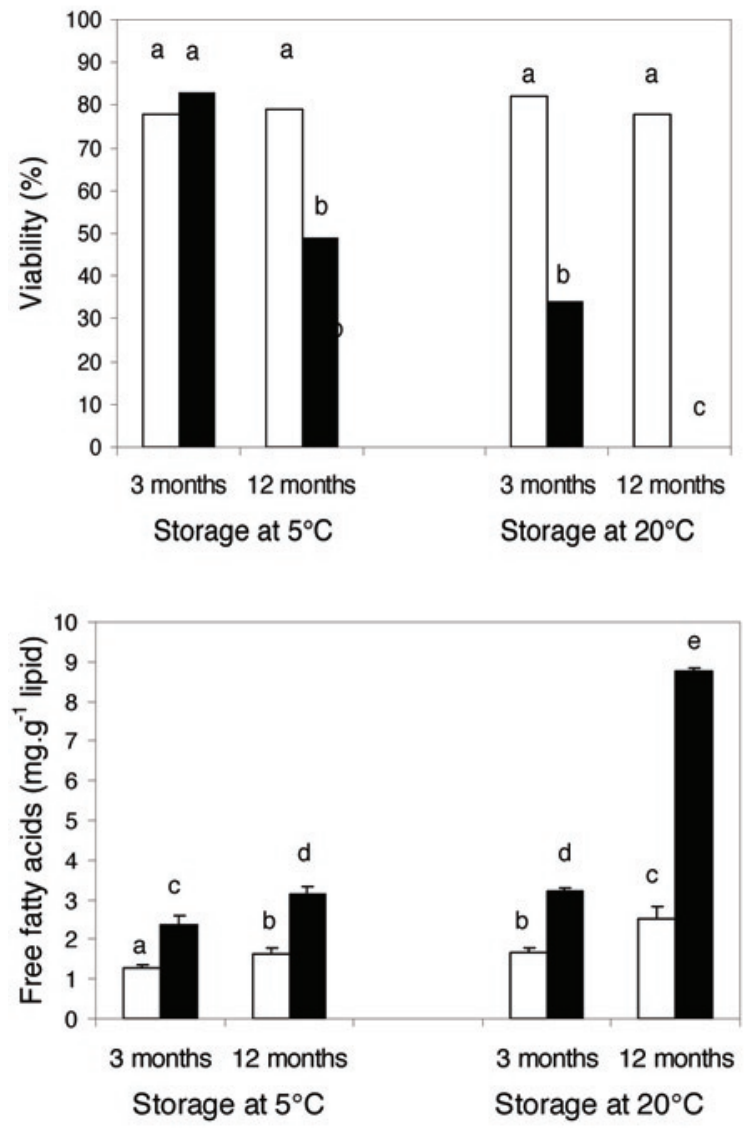

Figure 7. Effect of the time of storage at $5^{\circ} \mathrm{C}$ and $20^{\circ} \mathrm{C}$ on viability (under optimal rehydration conditions) and free fatty acid content of $C$. arabica seeds after drying under 45 $\%$ RH (white bars) and $81 \%$ RH (black bars). Bars showing by the same letter are not significantly different at $\mathrm{P}=0.05$ according to the Newman and Keuls test. Adapted from Dussert et al. (2006).

coffee species should result in a better understanding of seed longevity and appropriate commercial seed and germplasm storage protocols. Little is known about the molecular physiology and developmental anatomy of the transient perisperm, endosperm and embryo, which are likely to contribute to, and influence many parameters related to the final quality of ripe seeds. In addition, coffee seeds show slow germination, as well as slow seedling establishment. The recent completion of the Brazilian Coffee Genome Project (Vieira et al., 2005), among other international coffee genome efforts, offers the possibility of better understanding at the molecular level of fruit and seed maturation, desiccation tolerance and storage, germination and subsequently, establishment of the coffee seedling and survival. The coffee EST databases together with new technologies developed recently, such as high throughput sequencing analyses, transcriptomics and proteomics can be used to investigate and identify genes associated with these key events. Furthermore, functional genomics can be used to help unravel the biological function of a particular gene, leading to a better understanding of physiological processes in the coffee seed and seedling.

\section{REFERENCES}

Alvim PT (1973) Factors affecting flowering of coffee. In: SRB, A.M. (ed), Genes, enzymes and population, pp.193202. Plenum Press, New York.

Arcila-Pulgarín MI, Orozco-Castaño FJ (1987) Estudio morfologico del desarrollo del embrion de cafe. Cenicafé 38:62-63.

Bacchi O (1958) Estudos sobre a conservação de sementes. IV. Café. Bragantia 17:261-270.

Bacchi O (1959) Equilíbrio higroscópico de sementes de café, fumo e varias hortaliças. Bragantia 18:225-232.

Becwar MR, Stanwood PC, Lehonardt KW (1983) Dehydration effects on freezing characteristics and survival in liquid nitrogen of desiccation-tolerant and desiccation-sensitive seeds. J. Am. Soc. Hort. Sci. 108:613-618.

Bentsink L, Alonso-Blanco C, Vreugdenhil D, Tesnier K, Groot SPC, Koornneef M (2000) Genetic analysis of seed-soluble oligosaccharides in relation to seed storability of $\mathrm{Ara}$ bidopsis. Plant Physiol. 124:1595-1604.

Berry T, Bewley JD (1991) Seeds of tomato (Lycopersicon esculentum Mill.) which develop in a fully hydrated environment in the fruit switch from a developmental to a germinative mode without a requirement for desiccation. Planta 186:27-34.

Berry T, Bewley J.D. (1992) A role for the surrounding fruit tissue in preventing the germination of tomato (Lycopersicon esculentum) seeds. Plant Physiol. 100:951-957.

Berthaud J, Charrier A (1988) Genetic resources of Coffea. In: Clarke RJ, Macrae R (eds) Coffee, vol. 4, Agronomy. pp.1-42. Elsevier Applied Science, London.

Bewley JD, Black M (1994) Seeds - Physiology of development and germination. Plenum Press, New York, London.

Bewley JD, Kermode AR, Mirsa S (1989) Desiccation and minimal drying treatments of seeds of castor bean and Phaseolus vulgaris which terminate development and promote germination cause changes in protein and messenger RNA syntheses. Ann. Bot. 63:3-17.

Bochicchio A, Vernieri P, Puliga S, Balducci F, Vazzana C (1996) Desiccation tolerance in immature embryos of maize: sucrose, raffinose and ABA-sucrose relation. In: Proceedings of the International Workshop on Seeds: basic and applied aspects of seed biology, 1995, Reading, University of Reading, pp.1-12.

Brandão Junior DS (2000) Marcadores da tolerância à dessecação de sementes de cafeeiro. Lavras, Universidade Federal de Lavras. 144p. PhD thesis.

Camargo DM, Groth D, Razera LF (1993) Armazenamento de sementes de café (Coffea canephora L. cv. Guarini) condicionadas em dois tipos de embalagens após secagem natural e artificial. Rev. Bras. Sem. 15:87-95. 
Campa C, Noirot M, Bourgeois M, Pervent M, Ky CL, Chrestin H, Hamon S, de Kochko A (2003) Genetic mapping of a caffeoyl-coenzymeA 3-O-methyltransferase gene in coffee trees: impact on chlorogenic acid content. Theor. Appl. Gen. 107:751-756.

Carelli MLC, Monaco LC (1977) Conservação de sementes de café racemosa. Bragantia 36:XXXI-XXXIV.

Carvalho A, Medina Filho HP, Fazuoli LC, Guerreiro Filho O, Lima MMA (1991) Aspectos genéticos do cafeeiro. Rev. Bras. Genet. 14:135-183.

Carvalho MM, Alvarenga G (1979) Determinação do estádio de desenvolvimento mínimo do fruto do cafeeiro (Coffea arabi$c a \mathrm{~L}$ ) para germinação. In: Congresso Brasileiro de Pesquisas Cafeeiras, 1979, Araxá, MG, Brasil. pp.118-119.

Carvalho NM, Nakagawa J (1980) Sementes: ciência, tecnologia e produção. Campinas, Fundação Cargill, 326p.

Carvalho NM, Yanai L (1976) Maturação de sementes de trigo (Triticum aestivum L.) Científica 4:33-38.

Chabrillange N, Dussert S, Engelmann F, Doulbeau S, Hamon S (2000) Desiccation tolerance in relation to soluble sugar contents in seeds of ten coffee (Coffea L.) species. Seed Sci. Res. 10:393-396.

Crowe JH, Hoekstra FA, Crowe LM (1992) Anhydrobiosis. Ann. Rev. Plant Physiol. 54:579-599.

Da Silva EAA (2002) Coffee (Coffea arabica cv. Rubi) seed germination: mechanism and regulation. Wageningen, Wageningen Agricultural University. $\mathrm{PhD}$ thesis.

Da Silva EAA, Toorop PE, Jaap Nijsse J, Bewley JD, Hilhorst HWM (2005) Exogenous gibberellins inhibit coffee (Coffea arabica cv.Rubi) seed germination and cause cell death in the embryo. J. Exp. Bot. 56:1029-1038.

Da Silva EAA, Toorop PE, van Aelst AC, Hilhorst HWM (2004) Abscisic acid controls embryo growth potential and endosperm cap weakening during coffee (Coffea arabica cv. Rubi) seed germination. Planta 220:251-261.

De Castro RD, Estanislau WT, Carvalho MLM, Hilhorst HWM (2004) Functional development and (pre-)maturation of coffee (Coffea arabica) fruits and seeds. In: XX International Conference on Coffee Science, 2004, Bangalore, India.

De Castro RD, Hilhorst HWM (2000) Dormancy, germination and the cell cycle in developing and imbibing tomato seeds. Braz. J. Plant Physiol. 12:105-136.

De Castro RD, Marraccini P (2005) - in this issue

Dedecca DM (1957) Anatomia e desenvolvimento ontogenético de Coffea arabica L. var. Typica Cramer. Bragantia 16: 315-355.

Dentan E (1985) The microscopic structure of coffee bean. In: Clifford MF, Wilson KC (eds), Coffee: botany, biochemistry and production of beans and beverage, pp.284-304. The Avi Publishing Company, Westport.

Dias MCLL, Barros ASR (1993) Conservação de sementes de café (Coffea arabica L.) em diferentes embalagens. Rev. Bras. Sem. 15:197-202.

Dussert S, Chabrillange N, Engelmann F, Anthony F, Hamon $\mathrm{S}$ (1997) Cryopreservation of coffee (Coffea arabica L.) seeds: importance of the precooling temperature. CryoLetter 18:269-276.
Dussert S, Chabrillange N, Engelmann F, Anthony F, Louarn J, Hamon S (1998) Cryopreservation of seeds of four coffee species (Coffea arabica, C. costatifructa, C. racemosa and $C$. sessiliflora): importance of water content and cooling rate. Seed Sci. Res. 8:9-15.

Dussert S, Chabrillange N, Engelmann F, Hamon S (1999) Quantitative estimation of seed desiccation sensitivity using a quantal response model: application to nine species of the genus Coffea L. Seed Sci. Res. 9:135-144.

Dussert S, Chabrillange N, Montillet JL, Agnel JP, Engelmann F, Noirot M (2003) Basis of coffee seed sensitivity to liquid nitrogen exposure: oxidative stress or imbibitional damage? Physiol. Plant. 119:534-543.

Dussert S, Chabrillange N, Rocquelin G, Engelmann F, Lopez M, Hamon S (2001) Tolerance of coffee (Coffea spp.) seeds to ultralow temperature exposure in relation to calorimetric properties of tissue water, lipid composition and cooling procedure. Physiol. Plant. 112:495-504.

Dussert S, Chabrillange N, Vasquez N, Engelmann F, Anthony F, Guyot A, Hamon S (2000) Beneficial effect of post-thawing osmoconditioning on the recovery of cryopreserved coffee (Coffea arabica L.) seeds. CryoLetter 21:47-52.

Dussert S, Davey MW, Laffargue A, Doulbeau S, Swennen R, Etienne H (2006) Oxidative stress, phospholipid loss and lipid hydrolysis during drying and storage of intermediate seeds. Physiol. Plant. in press.

Dussert S, Engelmann F, Louarn J, Noirot M (2004) Inheritance of seed desiccation sensitivity in a coffee inter-specific cross: evidence for polygenic determinism. J. Exp. Bot. 55:1541-1547.

Eira MTS (1999) Estudos biofísicos da tolerância à desidratação e baixa temperatura em sementes e embriões de Coffea. Brasília, Universidade de Brasília. PhD thesis.

Eira MTS, Fazuoli LC, Santos FNR (2004) Cryopreservation of Coffea genetic resources in Brazil. In: XX International Conference on Coffee Science, 2004, Bangalore, India. pp.85.

Eira MTS, Walters C, Caldas LS (1999b) Water sorption properties in Coffea spp. seeds and embryos. Seed Sci. Res. 9: 321-330

Eira MTS, Walters C, Caldas LS, Fazuoli LC, Sampaio JB, Dias MCC (1999a) Tolerance of Coffea spp. seeds to desiccation and low temperature. Rev. Bras. Fisiol. Veg. 11: 97-105.

Eira MTS, Walters C, Reis RB, Hill LM (2002) Conservation of genetic resources of Coffea using cryopresevation. In: International Workshop on Seed Biology, 7, Salamanca, 2002. pp. 191.

Ellis RH, Hong TD, Roberts EH (1990) An intermediate category of seed storage behaviour? I. Coffee. J. Exp. Bot. 41:1167-1174.

Ellis RH, Hong TD, Roberts EH (1991) An intermediate category of seed storage behaviour? II. Effects of provenance, immaturity and imbibition on desiccation tolerance in coffee. J. Exp. Bot. 42:653-657.

Estanislau WT (2002) Modelo funcional de desenvolvimento de sementes de cafeeiro (Coffea arabica). Lavras, Universidade Federal de Lavras. MSc Thesis. 
Fazuoli LC (1986) Genética e melhoramento do cafeeiro. In: Rena AB, Malavolta E, Rocha M, Yamada T (eds), Cultura do cafeeiro - fatores que afetam a produtividade. pp.87113. Associação Brasileira para Pesquisa da Potassa e do Fosfato, Piracicaba.

Gentil DFO, Silva WR, Miranda DM (2001) Grau de umidade e temperatura na conservação de sementes de café. Bragantia 60:53-64.

Giorgini JF (1992) Purification and partial characterization of two isozymes of cellulase from GA3-treated coffee endosperm. Rev. Bras. Fisiol. Veg. 4:75-80.

Giorgini JF, Campos CASP (1992) Changes in the content of soluble sugars and starch synthesis and degradation during germination and seedling growth of Coffea arabica L. Rev. Bras. Fisiol. Veg. 4:11-15.

Gong X, Bassel GW, Wang A, Greenwood JS, Bewley JD (2004) The emergence of embryos from hard seeds is related to the structure of the cell walls of the micropylar endosperm, and not to endo-ß-mannanase activity. Ann. Bot. 96:1165-1173.

Guerreiro Filho O (1992) Coffea racemosa Lour. Une revue. Café Cacao Thé XXXVI:171-186.

Guimarães RM (1999) Fisiologia de sementes. Lavras, Universidade Federal de Lavras/ FAEPE. 129p.

Hilhorst HWM, Karssen CM (1992) Seed dormancy and germination: The role of abscisic acid and gibberellins and the importance of hormone mutants. Plant Growth Regul. 11:225-238.

Hong TD, Ellis RH (1992) Optimum air-dry seed storage environments for arabica coffee. Seed Sci. Technol. 20:547560 .

Hong TD, Ellis RH (1995) Interspecific variation in seed storage behaviour within two genera - Coffea and Citrus. Seed Sci. Technol. 23:165-181.

Hong TD, Ellis RH (2002) Optimum moisture status for the exceptional survival of seeds of arabica coffee (Coffea arabica L.) in medium-term storage at $-20^{\circ} \mathrm{C}$. Seed Sci. Technol. 30:131-6.

Hor YL, Stanwood PC, Chin HF (1993) Cryopreservation of Coffea liberica seeds and embryos following desiccation and freezing temperatures. Pertanika J. Trop. Agric. Sci. 16:75-80.

Huxley PA (1964) Some factors which can regulate germination and influence viability of coffee seeds. Proc. Intern. Seed Test Assoc. 29:33-60.

Institut de Recherche pour le Développement (2000) First cryopreservation seed bank for arabica coffee. Montpellier, IRD. (IRD Scientific Bulletins, 117).

Jacinto JBC, Carvalho NM (1974) Maturação de sementes de soja (Glycine max Merril). Científica 1:81-88.

Karssen CM, Zagorski S, Kepczynski J, Groot SPC (1989) A key role for endogenous gibberellins in the control of seed germination. Ann. Bot. 63:71-80.

King MW, Roberts EH (1979) The storage of recalcitrant seeds - achievements and possible approaches. Rome, IBPGR.

Krug CA, Carvalho A (1939) Genetical proof of the existence of coffee endosperm. Nature 144:515.
Leopold AC, Sun WQ, Bernal-Lugo I (1994) The glassy state in seeds: analysis and function. Seed Sci. Res. 4:267-274.

Lin TP, Huang NH (1994) The relationship between carbohydrate composition of some tree seeds and their longevity. J. Exp. Bot. 45:1289-1294.

Maestri M, Barros RS (1977) Coffee. In: Alvim PT, Kozlowski F (eds), Ecophysiology of tropical crops, pp.249-278. Academic Press, New York.

Maestri M, Vieira C (1961) Nota sobre a redução da porcentagem de germinação de sementes de café por efeito do ácido giberélico. Rev. Ceres 11:247-249.

Marraccini P, Rogers WJ, Allard C (2001) Molecular and biochemical characterization of endo- $\beta$-mannanase from germinating coffee (Coffea arabica) grains. Planta 213:296308.

Medina Filho HP, Carvalho A, Sondahl MR, Fazuoli LC, Costa WM (1984) Coffee breeding and related evolutionary aspects. Plant Breed. Rev. 2:157-193.

Mendes AJT (1941) Cytological observations in Coffea. VI. Embryo and endosperm development in Coffea arabica L. Am. J. Bot. 28:784-789.

Miranda JM, Carvalho MM, Carvalho ML, Vieira MG (1993) Estudos de alguns fatores que influenciam a viabilidade de sementes de café. Rev. Bras. Sem. 15:215-220.

Miura K, Lin SY, Yano M, Nagamine T (2002) Mapping quantitative trait loci controlling seed longevity in rice (Oryza sativa L.). Theor. Appl. Gen. 104:981-986.

Normah MN, Vengadasalan M (1992) Effects of moisture content on crypreservation of Coffea and Vigna seeds and embryos. CryoLetter 13:199-208.

Pammenter NW, Berjak P (1999) A review of recalcitrant seed physiology in relation to desiccation-tolerance mechanisms. Seed Sci. Res. 9:13-37.

Ramaiah PK, Vasudeva N (1969) Observations on the growth of coffee berries in south India. Turrialba, 19:544-464.

Rena AB, Malavolta E, Rocha M, Yamada T (1986) Cultura do cafeeiro - fatores que afetam a produtividade. Potafos, Piracicaba.

Roberts EH (1973) Predicting the storage life of seeds. Seed Sci. Technol. 1:499-514.

Rosa SDVF, Brandão Junior DS, von Pinho EVR, Veiga AD, Silva LHC (2005) Effects of different drying rates on the physiological quality of Coffea canephora Pierre seeds. Braz. J. Plant Physiol. 17:199-205.

Silva CM (1974) Maturação da semente e da determinação da época adequada de colheita do feijoeiro (Phaseolus vulgaris L.). Viçosa, Universidade Federal de Viçosa. MSc thesis.

Simmonds NW (1979) Genetic conservation: an introductory discussion of needs and principles. In: International Board for Plant Genetic Resources. Seed Technology for Genebanks. pp. 1-11. Rome, IBPGR.

Stanwood PC (1985) Cryopreservation of seed germplasm for genetic conservation. In: Kartha KK (ed), Cryopreservation of plant cell and organs, pp. 199-226. CRC Press, Boca Raton.

Steadman KJ, Pritchard HW, Dey PM (1996) Tissue-specific soluble sugars in seeds as indicator of storage category. Ann. Bot. 77:667-674. 
Sun WQ, Koh DCY, Ong CM (1997) Correlation of modified water sorption properties with the decline of storage stability of osmotically-primed seeds of Vigna radiata (L.) Wilczek. Seed Sci. Res. 7:391-397.

Takaki M, Dietrich SMC, Furtado JS (1979) Anatomical changes in the hard endosperm of gibberellic acid-treated coffee seeds during germination. Rev. Bras. Bot. 2: 103-106.

Takaki M, Dietrich SMC (1979) Effect of gibberellic acid on peroxidase from coffee seeds during germination. Hoennea 8:29-33.

Takaki M, Dietrich SMC (1980) Effect of GA3 and light on polysaccharide levels and metabolism in germinating coffee seeds. J. Exp. Bot. 31:1643-1649.

Valio IFM (1976) Germination of coffee seeds (Coffea arabica L. cv. Mundo Novo). J. Exp. Bot. 27:983-991.

Valio IFM (1980) Inhibition of germination of coffee seeds (Coffea arabica L. cv. Mundo Novo) by the endocarp. J. Seed Technol. 5:32-39.

Van der Vossen HAM (1979) Methods of preserving the viability of coffee seed in storage. Seed Sci. Technol. 7:65-74.

Vasquez N, Salazar K, Anthony A, Chabrillange N, Engelmann F, Dussert S (2005) Variability in response of seeds to liquid nitrogen exposure in wild coffee (Coffea arabica L.). Seed Sci. Technol. 33:293-301.

Vertucci CW (1990). Calorimetric studies of the state of water in seed tissues. Biophys. J. 58:1463-1170.

Vertucci CW, Farrant JM (1995) Acquisition and loss of desiccation tolerance. In: Kigel J, Galilli G. (eds) Seed development and germination, pp.237-271. Marcel Dekker, New York.
Vertucci CW, Leopold AC (1987) The relationship between water binding and desiccation tolerance in tissues. Plant Physiol. 85:232-238.

Vertucci CW, Roos EE (1990) Theoretical basis of protocols for seed storage. Plant Physiol. 94:1019-1023.

Vertucci CW, Crane J, Porter RA, Oelke EA (1994) Physical properties of water in Zizania embryos in relation of maturity status, water content and temperature. Seed Sci. Res. 4:211-224.

Vieira LGE, Andrade AC, Colombo CA, Pereira GAG (2005) Coffee genome project: a resource for functional genomics. In: Zambolim L, Zambolim EM, Várzea VMP (eds) Durable resistance to coffee leaf rust, pp. 363-395. Editora da Universidade Federal de Viçosa, Viçosa.

Wellman FL (1961) Coffee: botany, cultivation, and utilization. London, Leonard Hill.

Wellman FL, Toole VK (1960) Coffee seed germination as affected by species, diseases and temperature. Proc. Caribbean Region Am. Soc. Hort. Sci. 4:1-6.

Went FW (1957) The experimental control of plant growth. Ronald Press, New York.

Williams RJ, Leopold AC (1989) The glassy state in corn embryos. Plant Physiol. 89:977-981.

Wolfrom ML, Laver ML, Patin DL (1961) Carbohydrates of coffee bean. II. Isolation and characterization of a mannan. J. Org. Chem. 26:4533-4536.

Wolfrom ML, Patin DL (1964) Isolation and characterization of cellulose in the coffee bean. Agric. Food Chem. 12:376-377.

Wormer TM (1964) The growth of the coffee berry. Ann. Bot. 28:47-55. 